\title{
Bibliography
}

\section{Archives and collections}

British Film Institute National Film Archive, BFI Reuben Library, London

Press cuttings files

Pressbooks

British Film Institute National Film Archive, Special Collections, London

British Board of Film Censors (BBFC) collection

Michael Balcon collection

Unpublished scripts

The Museum of the Home (formerly the Geffrye Museum of the Home), London

Furniture catalogues collection

London Transport Museum, London

Ephemera collection, Metro-Land booklet, Metropolitan Railway (1921)

Mass-Observation Archive, University of Sussex

Mass-Observation directives, Report on Mantelpieces (1937)

Museum of Domestic Design \& Architecture Archive, Middlesex University, London

Crown Wallpaper Magazine (1939) 
Victoria and Albert Museum, Archive of Art and Design, London

Ideal Home Exhibition catalogues and photograph albums, AAD/1990/9 Daily Mail Ideal Home Exhibition: Records

Victoria and Albert Museum, Theatre and Performance Archives, London

Michael Denison and Dulcie Gray, THM Biographical file

\section{Periodicals}

Geographical Magazine

Homes and Gardens

Ideal Home

Kinematograph Weekly

Modern Home

Modern Woman

My Home

Picturegoer

Picture Post

The Tatler

Woman and Home

Woman's Own

\section{Contemporary publications}

Baldwin, S. On England: And Other Addresses. London: Philip Allan and Company, 1946 (first pub. 1926).

Bendit, P. and L. J. Bendit. Living Together Again. London: Gramol Publications, 1946.

Bertram, A. Design in Everyday Things. London: British Broadcasting, Corporation, 1937.

Betjeman, J. Continual Dew: A Little Book of Bourgeois Verse. London: John Murray, 1937.

Blunden, E. English Villages. London: William Collins, 1941.

British Traditional Colours. Souvenir in Connection with the Coronation of His Majesty King George VI and Her Majesty Queen Elizabeth. London: British Colour Council, 1937.

Carrick, E. Art and Design in the British Film: A Pictorial Directory of British Art Directors and Their Work. London: Dennis Dobson, 1948.

Cheveley, S. A Garden Goes to War. London: John Miles, 1940.

Coglan, W. N. The Readership of Newspapers and Periodicals in Great Britain, 1936. A Report on Circulation Directed by W. N. Coglan. London: Incorporated Society of British Advertisers, 1937. 
Collier, J. W. A Film in the Making ... Featuring "It Always Rains on Sunday". London: World Film Publications, 1947.

Coward, N. Still Life, A Play, Etc. London: Samuel French, 1938.

Daily Mail Film Award Annual, British Films of 1947. London: Winchester Publications, 1948.

Ford, C. B. England in Colour: A Short Survey of the English Landscape and Its Antiquities. London: B. T. Batsford, 1939 (first pub. 1937).

Forshaw, J. H. and P. Abercrombie. County of London Plan. London: Macmillan, 1943.

Freud, S. 'The Uncanny', in V. B. Leitch (ed.) The Norton Anthology of Theory and Criticism, pp. 929-52. New York: W. W. Norton \& Company, 1919.

Grant, M. C. and F. Fox (collab.). The British Empire Exhibition Catalogue. London, 1924.

Lee, S. British Film Stars at Home. London: Findon Publications, 1947.

Lehmann, R. The Weather in the Streets. Harmondsworth: Penguin, 1972 (first pub. 1936).

Lejeune, C. A. Chestnuts in Her Lap, 1936-1947. London: Phoenix House, 1948 (first pub. 1947).

Mannon, W., A. D. Miller, and N. Phipps. Spring in Park Lane ... Adapted from the Screenplay by Nicholas Phipps. Based on a Novel 'Come out of the Pantry' by Alice Duer Miller. London: World Film Publications, 1948.

Manvell, R. Three British Screenplays. London: Methuen \& Co, 1950.

Morgan, G. Only Ghosts Can Live. London: Crosby Lockwood \& Son, 1945.

Orwell, G. The Lion and the Unicorn: Socialism and the English Genius. London: Secker \& Warburg, 1941.

- The Road to Wigan Pier. London: Penguin Books, in association with Martin Secker \& Warburg, 2001 (first pub. 1937).

Pleydell-Bouverie, M. Daily Mail Book of Post War Homes: Based on the Ideas and Opinions of the Women of Britain. London: Daily Mail, Ideal Home Exhibition Dept of Associated Newspapers Ltd, 1944.

Priestley, J. B. English Journey. London: William Heinemann, in association with Victor Gollancz, 1934.

- Letter to a Returning Serviceman. London: Home \& Van Thal Ltd, 1945.

Recording Britain Volume I-IV, text by Arnold Palmer. London: Oxford University Press, in association with The Pilgrim Trust, 1949.

Richards, J. M. The Castles on the Ground: The Anatomy of Suburbia. London: John Murray, 1973 (first pub. 1946).

Stannage, R. Stars by Day: A Tour in Words and Pictures of the British Film Studios. London: The Film Book Club, 1947.

Struther, J. Mrs Miniver. London: Chatto \& Windus, 1942 (first pub. 1937).

Woolf, V. The Death of the Moth, and Other Essays. London: Hogarth Press, 1942. 


\section{Secondary publications}

Addison, P. Now the War Is Over: A Social History of Britain 1945-51. London: Pimlico, 1995.

Anolik, R. B. and D. L. Howard, eds. The Gothic Other: Racial and Social Constructions in the Literary Imagination. Jefferson, NC: McFarland \& Company, 2004.

Artmonsky, R. A Snapper Up of Unconsidered Trifles: A Tribute to Barbara Jones. London: Artmonsky Arts, 2008.

Atha, C. 'Dirt and Disorder: Taste and Anxiety in the Homes of the British Working Class', in R. Schuldenfrei (ed.) Atomic Dwelling: Anxiety, Domesticity, and Postwar Architecture, pp. 207-26. Abingdon, Oxon: Routledge, 2012.

Atkinson, H. The Festival of Britain: A Land and Its People. London: I. B. Tauris, 2012.

Babington, B. British Stars and Stardom: From Alma Taylor to Sean Connery. Manchester: Manchester University Press, 2001.

Barnett, C. The Lost Victory: British Dreams, British Realities, 1945-1950. London: Faber \& Faber, 2011.

Barr, C. All Our Yesterdays: 90 Years of British Cinema. London: BFI, 1986.

—_, Ealing Studios. London: Studio Vista, 1993 (first pub. 1977).

Barrett, H., and J. Phillips. Suburban Style: The British Home, 1840-1960. London: Macdonald and Company, 1987.

Beauman, N. A Very Great Profession: The Woman's Novel 1914-39. London: Virago Press, 1983.

Bell, M. Femininity in the Frame: Women and 1950s British Popular Cinema. London:

I. B. Tauris, 2010.

Bell, M. and M. Williams, eds. British Women's Cinema. London: Routledge, 2010.

Benjamin, W. 'Theses on the Philosophy of History', in H. Arendt (ed.) Illuminations, pp. 245-55. London: Pimlico, 1999 (first pub. 1942).

- The Arcades Project, translation by H. Eiland and K. Mclaughlin. Cambridge, MA: The Belknap Press of Harvard University Press, 2002.

- One-Way Street and Other Writings, translation by J. A. Underwood. London: Penguin, 2009.

Benton, T. The Modernist Home. London: V\&A Publications, 2006.

Berman, M. All That Is Solid Melts into Air: The Experience of Modernity. New York: Simon and Schuster, 1982.

Bingham, A. Gender, Modernity, and the Popular Press in Inter-War Britain. Oxford: Clarendon Press, 2004.

Blackwell, T. and J. Seabrook. A World Still to Win: The Reconstruction of the Post-War Working Class. London: Faber \& Faber, 1985.

Bluemel, K. ed. Intermodernism: Literary Culure in Mid-Twentieth Century Britain. Edinburgh: Edinburgh University Press, 2009.

Bracco, R. M. Merchants of Hope: British Middlebrow Writers and the First World War, 1919-39. Oxford: Berg, 1993.

Briganti, C. and K. Mezei. 'House Haunting: The Domestic Novel of the Inter-War Years', Home Cultures 1:2 (2004), 147-68. 
Brown, G. with T. Aldgate. The Common Touch: The Films of John Baxter. London: National Film Theatre, 1989.

Brown, M. and C. Harris. The Wartime House: Home Life in Wartime Britain, 1939-1945. Stroud: Sutton Publishing, 2001.

Brown, S. 'Technical Appendix', in S. Street, Colour Films in Britain: The Negotiation of Innovation 1900-55, pp. 259-87. London: Palgrave Macmillan on behalf of the BFI, 2012.

Brownlow, K. David Lean: A Biography. London: Richard Cohen, 1996.

Brunsdon, C. London in Cinema: The Cinematic City since 1945. London: BFI, 2007.

Bullock, N. Building the Post-War World: Modern Architecture and Reconstruction in Britain. London: Routledge, 2002.

Burton, A. and T. O'Sullivan, eds. The Cinema of Basil Dearden and Michael Relph. Edinburgh: Edinburgh University Press, 2009.

Casey, E. S. Getting Back into Place: Toward a Renewed Understanding of the Place-World. Bloomington, IN: Indiana University Press, 2009 (first pub. 1993).

Clapson, M. 'Destruction and Dispersal: The Blitz and the "Break-up" of Working-Class London', in M. Clapson and P. J. Larkham (eds) The Blitz and Its Legacy: Wartime Destruction to Post-War Reconstruction, pp. 99-112. Farnham: Ashgate Publishing Ltd, 2013.

- Invincible Green Suburbs, Brave New Towns: Social Change and Urban Dispersal in Post-War England. Manchester: Manchester University Press, 1998.

Collins, J. and J. Jervis, eds. Uncanny Modernity: Cultural Theories, Modern Anxieties. Basingstoke: Palgrave Macmillan, 2008.

Conekin, B. "'Here Is the Modern World Itself”: The Festival of Britain's Representations of the Future', in B. Conekin, F. Mort and C. Waters (eds) Moments of Modernity: Reconstructing Britain, 1945-1964, pp. 228-46. London: Rivers Oram Press, 1999.

Conekin, B., F. Mort and C. Waters, eds. Moments of Modernity: Reconstructing Britain, 1945-1964. London: Rivers Oram Press, 1999.

Cox, H., and S. Mowatt. Revolutions from Grub Street: A History of Magazine Publishing in Britain. Oxford: Oxford University Press, 2014.

Cutforth, R. Later Than We Thought: A Portrait of the Thirties. Newton Abbot: David and Charles, 1976.

Danischewsky, M. White Russian: Red Face. London: Victor Gollancz, 1966.

Daunton, M. J. and B. Rieger, eds. Meanings of Modernity: Britain from the Late Victorian Era to World War II. Oxford: Berg, 2001.

Davidoff, L., J. L'esperance and H. Newby. 'Landscape with Figures: Home and Community in English Society', in J. Mitchell and A. Oakley (eds) The Rights and Wrongs of Women, pp. 139-75. Middlesex: Penguin, 1977.

Davies, A. 'A Cinema in Between: Postwar British Cinema', in A. Davies and A. Sinfield (eds) British Culture of the Postwar: An Introduction to Literature and Society 19451999, pp. 110-24. London: Routledge, 2000.

- Leisure, Gender, and Poverty: Working-Class Culture in Salford and Manchester, 1900-1939. Buckingham: Open University Press, 1992. 
D'Cruze, S. “"The damned place was haunted”: The Gothic, Middlebrow Culture and Inter-War "Notable Trials", Literature and History 15 (2006), 37-58.

Denison, M. Double Act. London: Michael Joseph, 1985.

—. Overture and Beginners. London: Gollancz, 1973.

Doane, M. A. The Desire to Desire: The Woman's Film of the 1940s. Bloomington, IN: Indiana University Press, 1987.

Dodd, K. and P. Dodd. 'Engendering the Nation: British Documentary Film, 1930-39', in A. Higson (ed.) Dissolving Views: Key Writings on British Cinema, pp. 38-50. London: Cassell, 1996.

Dolan, J. 'Post-War Englishness, Maytime in Mayfair, Utopian Visions and Consumer Culture', in C. Hart (ed.) Englishness, Diversity, Differences and Identity: A Collection of Original Papers Exploring Notions of Englishness, pp. 45-53. Kingswinford: Midrash Publications, 2007.

Downey, G. ed. Domestic Interiors: Representing Homes from the Victorians to the Moderns. London: Bloomsbury, 2013.

Duguid, M. and K. McGahan. 'From Tinsel to Realism and Back Again', in M. Duguid, L. Freeman, K. M. Johnston and M. Williams (eds) Ealing Revisited, pp. 58-70. London: BFI, 2012.

Durgnat, R. A Mirror for England: British Movies from Austerity to Affluence. London: Palgrave Macmillan on behalf of the BFI, 2011 (first pub. 1970).

Dyer, R. Brief Encounter. London: Palgrave Macmillan on behalf of the BFI, 2015 (first pub. 1993).

—. 'Entertainment and Utopia', in S. Cohan (ed.) Hollywood Musicals: The Film Reader, pp. 19-30. London: Routledge, 2012.

—. Stars. London: BFI, 1998 (first pub. 1979).

Ede, L. N. British Film Design: A History. London: I. B. Tauris, 2010.

Edwards, A. M. The Design of Suburbia: A Critical Study in Environmental History. London: Pembridge, 1981.

Ellis, J. 'The Quality Film Adventure: British Critics and the Cinema, 1942-8', in A. Higson (ed.) Dissolving Views: Key Writings on British Cinema, pp. 66-93. London: Cassell, 1996.

Elsaesser, T. 'Tales of Sound and Fury: Observations on the Family Melodrama', in C. Gledhill (ed.) Home Is Where the Heart Is: Studies in Melodrama and the Woman's Film, pp. 43-69. London: British Film Institute, 1987 (first pub. in Monogram 4, 1972).

Finch, J. and P. Summerfield. 'Social Reconstruction and the Emergence of the Companionate Marriage, 1945-59', in D. Clark (ed.) Marriage, Domestic Life and Social Change, pp. 6-28. London: Routledge, 1991.

Foucault, M. 'Of Other Spaces', Diacritics 16 (1986), 22-7.

—. 'What Is Enlightenment?', in P. Rabinow (ed.) The Foucault Reader, pp. 32-50. London: Penguin, 1991 (first pub. 1986).

Friedberg, A. Window Shopping: Cinema and the Postmodern. Berkeley, CA: University of California Press, 1993.

Frizzell, D. Humphrey Spender's Humanist Landscapes: Photo-Documents, 1932-1942. 
New Haven, CT: Yale Center for British Art/Paul Mellon Centre for Studies in British Art, 1997.

Gan, W. Women, Privacy and Modernity in Early Twentieth-Century British Writing. Basingstoke: Palgrave Macmillan, 2009.

Gardiner, J. Picture Post Women. London: Collins \& Brown, 1993.

Geraghty, C. British Cinema in the Fifties: Gender, Genre and the 'New Look'. London: Routledge, 2000.

Giles, J. The Parlour and the Suburb: Domestic Identities, Class, Femininity and Modernity. Oxford: Berg, 2004.

- Women, Identity and Private Life in Britain, 1900-50. Basingstoke: Macmillan, 1995.

Gillett, P. The British Working Class in Postwar Film. Manchester: Manchester University Press, 2003.

Gledhill, C. 'The Melodramatic Field: An Investigation', in C. Gledhill (ed.) Home Is Where the Heart Is: Studies in Melodrama and the Woman's Film, pp. 5-42. London: British Film Institute, 1987.

—. Reframing British Cinema, 1918-1928: Between Restraint and Passion. London: BFI, 2003.

Gledhill, C. and G. Swanson, eds. Nationalising Femininity: Culture, Sexuality and British Cinema in the Second World War. Manchester: Manchester University Press, 1996.

Hackney, F. “'Women Are News”: British Women's Magazines 1919-1939', in A. Ardis and P. Collier (eds) Transatlantic Print Culture, 1880-1940: Emerging Media, Emerging Modernisms, pp. 114-33. London: Palgrave Macmillan, 2008.

Hallett, M. The Real Story of 'Picture Post'. Birmingham: ARTicle Press, 1994.

Hansen, M. 'The Mass Production of the Senses: Classical Cinema as Vernacular Modernism', Modernism/Modernity 6 (1999), 59-77.

Hanson, H. Hollywood Heroines: Women in Film Noir and the Female Gothic Film. London: I. B. Tauris, 2007.

Harper, G. and J. Rayner, eds. Cinema and Landscape: Film, Nation and Cultural Geography. Bristol: Intellect, 2010.

Harper, S. 'The Ownership of Woods and Water: Landscapes in British Cinema 1930-1960', in G. Harper and J. Rayner (eds) Cinema and Landscape: Film, Nation and Cultural Geography, pp. 147-60. Bristol: Intellect, 2010.

- Women in British Cinema: Mad, Bad, and Dangerous to Know. London: Continuum, 2000.

Harper, S. and V. Porter. British Cinema of the 1950s: The Decline of Deference. Oxford: Oxford University Press, 2003.

Harris, A. Romantic Moderns: English Writers, Artists and the Imagination from Virginia Woolf to John Piper. London: Thames \& Hudson, 2010.

Hayward, R. 'Desperate Housewives and Model Amoebae: The Invention of Suburban Neuroses in Inter-War Britain', in M. Jackson (ed.) Health and the Modern Home, pp. 42-62. London: Routledge, 2007.

Heathcote, E. The Meaning of Home. London: Frances Lincoln, 2012. 
Hewison, R. Culture and Consensus: England, Art and Politics since 1940. London: Methuen, 1995.

Highmore, B. The Great Indoors: At Home in the Modern House. London: Profile Books, 2014.

Higson, A. English Heritage, English Cinema: Costume Drama since 1980. Oxford: Oxford University Press, 2003.

—. 'Re-Constructing the Nation: This Happy Breed', in W. W. Dixon (ed.) Re-Viewing British Cinema, 1900-1992: Essays and Interviews, pp. 67-81. Albany, NY: State University of New York Press, 1994.

- 'Space, Place and Spectacle: Landscape and Townscape in the "Kitchen Sink” Film', in A. Higson (ed.) Dissolving Views: Key Writings on British Cinema, pp. 133-56. London: Cassell, 1996.

- Waving the Flag: Constructing a National Cinema in Britain. Oxford: Clarendon, 1995.

Hinds, H. 'Domestic Disappointments: Feminine Middlebrow Fiction of the Interwar Years', Home Cultures 6:2 (2009), 199-211.

Hockenhull, S. Aesthetics and Neo-Romanticism in Film: Landscapes in Contemporary British Cinema. London: I. B. Tauris, 2014.

- Neo-Romantic Landscapes: An Aesthetic Approach to the Films of Powell and Pressburger. Newcastle: Cambridge Scholars, 2008.

Hoggart, R. The Uses of Literacy: Aspects of Working-Class Life with Special Reference to Publications and Entertainments. London: Penguin Books, 1962 (first pub. 1957).

Hopkinson, T. Bert Hardy, Photojournalist. London: Gordon Fraser Gallery for Arts Council of Great Britain, 1975.

Hornsey, R. The Spiv and the Architect: Unruly Life in Postwar London. Minneapolis, MN: University of Minnesota Press, 2010.

Hubble, N. 'Imagism, Realism, Surrealism: Middlebrow Transformations in the MassObservation Project', in E. Brown and M. Grover (eds) Middlebrow Literary Cultures: The Battle of the Brows, 1920-1960, pp. 202-17. London: Palgrave Macmillan, 2012. Humble, N. The Feminine Middlebrow Novel, 1920s to 1950s: Class, Domesticity, and Bohemianism. Oxford: Oxford University Press, 2001.

Hutchings, P. 'Uncanny Landscapes in British Film and Television', Visual Culture in Britain 5 (2004) 27-40.

James, P. and R. Sadler. Homes Fit for Heroes: Photographs by Bill Brandt, 1939-1943. Stockport: Dewi Lewis in association with Birmingham Library Services, 2004.

Jeffery, T. 'A Place in the Nation: The Lower Middle Class in England', in R. Koshar (ed.)

Splintered Classes: Politics and the Lower Middle Classes in Interwar Europe, pp. 70-96. London: Holmes \& Meier, 1990.

Jones, B. and R. Searle. 'Humphrey Jennings, the Left and the Experience of Modernity', History Workshop Journal 75 (2013), 191-212.

Kirkham, P. and J. Thumim. 'Men at Work: Dearden and Gender', in A. Burton, T. O'Sullivan and P. Wells (eds) Liberal Directions: Basil Dearden and Postwar British Film Culture, pp. 89-107. Trowbridge: Flicks Books, 1997.

Kuhn, A. 'Cinema Culture and Femininity in the 1930s', in C. Gledhill and G. Swanson 
(eds) Nationalising Femininity: Culture, Sexuality and British Cinema in the Second World War, pp. 177-92. Manchester: Manchester University Press, 1996.

—. An Everyday Magic: Cinema and Cultural Memory. London: I. B. Tauris, 2002.

—. 'Film Stars in 1930s Britain: A Case Study in Modernity and Femininity', in

T. Soila (ed.) Stellar Encounters: Stardom in Popular Europen Cinema, pp. 180-94.

New Barnet: John Libbey Publishing, 2009.

—. Ratcatcher. Basingstoke: Palgrave Macmillan on behalf of the BFI, 2008.

—. 'Snow White in 1930s Britain', Journal of British Cinema and Television 7 (2010), 183-99.

Lack, R-F. “Local Film Subjects”: Suburban Cinema, 1895-1910', in P. Hirsch and C. O’Rourke (eds) London on Film, pp. 15-26. London: Palgrave Macmillan, 2017.

Landy, M. British Genres: Cinema and Society, 1930-1960. Princeton, NJ: Princeton University Press, 1991.

Langhamer, C. 'The Meanings of Home in Postwar Britain', Journal of Contemporary History 40 (2005), 341-62.

Lant, A. Blackout: Reinventing Women for Wartime British Cinema. Princeton, NJ: Princeton University Press, 1991.

Lay, S. British Social Realism: From Documentary to Brit Grit. London: Wallflower Press, 2002.

Lefebvre, M. ed. Landscape and Film. London: Routledge, 2006.

Lejeune, A. ed. The C. A. Lejeune Film Reader. Manchester: Carcanet, 1991.

Levine, C. 'Propaganda for Democracy: The Curious Case of Love on the Dole', Journal of British Studies 45 (2006), 846-74.

Light, A. Forever England: Femininity, Literature and Conservatism between the Wars. London: Routledge, 1991.

Linehan, D. 'A New England: Landscape, Exhibition and Remaking Industrial Space in the 1930s', in D. Gilbert, D. Matless and B. Short (eds) Geographies of British Modernity: Space and Society in the Twentieth Century, pp. 132-50. Oxford: Blackwell Publishing, 2003.

Lovell, A. 'The British Cinema: The Known Cinema?', in R. Murphy (ed.) The British Cinema Book, pp. 5-13. London: Palgrave Macmillan on behalf of the BFI, 2009 (first pub. 1997).

Low, R. The History of the British Film 1918-1929, Vol. IV. London: Allen \& Unwin, 1971.

Lowerson, J. 'Battles for the Countryside', in F. Gloversmith (ed.) Class, Culture and Social Change: A New View of the 1930s, pp. 258-80. Brighton: Harvester Press, 1980.

Macdonald, K. Emeric Pressburger: The Life and Death of a Screenwriter. London: Faber \& Faber, 1994.

Macdonald, K. The Masculine Middlebrow, 1880-1950: What Mr Miniver Read. London: Palgrave Macmillan, 2011.

Mandler, P. The Fall and Rise of the Stately Home. New Haven, CT and London: Yale University Press, 1997. 
- 'New Towns for Old: The Fate of the Town Centre', in B. Conekin, F. Mort and C. Waters (eds) Moments of Modernity: Reconstructing Britain 1945-1964, pp. 208-27. London: Rivers Oram Press, 1999.

—. 'The Consciousness of Modernity? Liberalism and the English National Character, 1870-1940', in M. J. Daunton and B. Rieger (eds) Meanings of Modernity: Britain from the Late Victorian Era to World War II, pp. 119-44. Oxford: Berg, 2001.

Marcou, D. J., All the Best: Britain's Picture Post Magazine, Best Mirror and Old Friend to Many, 1938-57. La Crosse, WI: DigiCOPY, 2010.

Marwick, A. British Society since 1945. London: Penguin, 1996 (first pub. 1982).

Matless, D. Landscape and Englishness. London: Reaktion, 1998.

McFarlane, B. An Autobiography of British Cinema: As Told by the Filmmakers and Actors Who Made It. London: Methuen, 1997.

—. 'Losing the Peace: Some British Films of Post-War Adjustment', in T. Barta (ed.) Screening the Past: Film and the Representation of History, pp. 93-108. New York: Praeger, 1998.

McKibbin, R. Classes and Cultures: England, 1918-1951. Oxford: Oxford University Press, 2000.

Medhurst, A. 'Myths of Consensus and Fables of Escape: British Cinema 1945-51', in J. Fyrth (ed.) Labour's Promised Land? Culture and Society in Labour Britain 1945-51, pp. 289-301. London: Lawrence \& Wishart, 1995.

Mellor, D. 'The Body and the Land: Neo-Romantic Art and Culture', in D. Mellor (ed.) A Paradise Lost: The Neo-Romantic Imagination in Britain 1935-55, pp. 15-86. London: Lund Humphries Publishers Ltd. in association with the Barbican Art Gallery, 1987.

Mengham, R. "'Anthropology at Home”: Domestic Interiors in British Film and Fiction of the 1930s and 1940s', in J. Aynsley and C. Grant (eds) Imagined Interiors: Representing the Domestic Interior since the Renaissance, pp. 244-55. London: V\&A Publications, 2006.

Mercer, J. and M. Shingler. Melodrama: Genre, Style and Sensibility. London: Wallflower, 2004.

Moen, K. Film and Fairy Tales: The Birth of Modern Fantasy. London: I. B. Tauris, 2013. Moor, A. Powell and Pressburger: A Cinema of Magic Spaces. London: I. B. Tauris, 2005. Mulvey, L. Death $24 x$ a Second: Stillness and the Moving Image. London: Reaktion, 2006.

Murphy, R. 'British Film Noir', in A. Spicer (ed.) European Film Noir, pp. 84-111. Manchester: Manchester University Press, 2007.

- Realism and Tinsel: Cinema and Society in Britain 1939-1949. London: Routledge, 1992 (first pub. 1989).

Napper, L. British Cinema and Middlebrow Culture in the Interwar Years. Exeter: University of Exeter Press, 2009.

—. 'Time and the Middlebrow in 1940s British Cinema', in S. Faulkner (ed.) Middlebrow Cinema, pp. 71-87. London: Routledge, 2016.

Nava, M. and A. O'Shea, eds. Modern Times: Reflections on a Century of English Modernity. London: Routledge, 1996. 
Nava, M. 'Modernity Tamed? Women and the Rationalisation of Consumption in the Interwar Period', Australian Journal of Communication 22 (1995), 1-19.

Nead, L. The Tiger in the Smoke: Art and Culture in Post-War Britain. London: Yale University Press for the Paul Mellon Centre for Studies in British Art, 2017.

Neame, R. Straight from the Horse's Mouth: Ronald Neame, an Autobiography, with Barbara Cooper. Oxford: Scarecrow Press, 2003.

Newland, P. The Cultural Construction of London's East End: Urban Iconography, Modernity and the Spatialisation of Englishness. Amsterdam: Rodopi, 2008.

Oliver, P., I. Davis and I. Bentley. Dunroamin: The Suburban Semi and Its Enemies. London: Barrie \& Jenkins, 1981.

O'Shea, A. 'English Subjects of Modernity', in M. Nava and A. O'Shea (eds) Modern Times: Reflections on a Century of English Modernity, pp. 7-37. London: Routledge, 1996.

Orr, J. Romantics and Modernists in British Cinema. Edinburgh: Edinburgh University Press, 2010.

Overy, R. The Morbid Age: Britain and the Crisis of Civilization, 1919-1939. London: Penguin Books, 2010.

Phillips, G. D. Beyond the Epic: The Life and Films of David Lean. Lexington, KY: University Press of Kentucky, 2006.

Phillips, P. 'The New Look', in M. Sissons and P. French (eds) Age of Austerity, 1945-51, pp. 127-48. London: Hodder \& Stoughton, 1963.

Price, H. '“A Living Set”: At Home with Vivien Leigh', in K. Dorney and M. B. Gale (eds) Vivien Leigh: Actress and Icon, pp. 215-37. Manchester: Manchester University Press, 2018.

__. "'A Somewhat Homely" Stardom: Michael Denison, Dulcie Gray and Refurnishing Domestic Modernity in the Postwar Years', Journal of British Cinema and Television 12:1 (2015), 25-44.

Pugh, M. 'We Danced All Night': A Social History of Britain between the Wars. London: Vintage Books, 2008.

Rattigan, N. This Is England: British Film and the People's War, 1939-1945. London: Associated University Presses, 2001.

Reed, C. ed. Not at Home: The Suppression of Domesticity in Modern Art and Architecture. London: Thames \& Hudson, 1996.

Rennie, P. Festival of Britain 1951. Woodbridge: Antique Collectors' Club, 2007.

Rice, C. The Emergence of the Interior: Architecture, Modernity, Domesticity. London: Routledge, 2007.

Richards, J. The Age of the Dream Palace: Cinema and Society in 1930s Britain. London: I. B. Tauris, 2010 (first pub. 1989).

—. 'Basil Dearden at Ealing', in A. Burton, T. O'Sullivan and P. Wells (eds) Liberal Directions: Basil Dearden and Postwar British Film Culture, pp. 14-35. Trowbridge: Flicks Books, 1997.

Richards, J. and D. Sheridan. Mass-Observation at the Movies. London: Routledge, 1987.

Rose, G. 'Engendering the Slum: Photography in East London in the 1930s', Gender, Place \& Culture: A Journal of Femininist Geography 4 (2010), 277-300. 
Rose, S. O. 'Temperate Heroes: Masculinity in Second World War Britain', in S. Dudink, K. Haggeman and J. Tosh (eds) Masculinity in Politics and War, pp. 177-95. Manchester: Manchester University Press, 2004.

- Which People's War? National Identity and Citizenship in Britain 1939-1945. Oxford: Oxford University Press, 2003.

Ryan, D. S. The Ideal Home through the 20th Century. London: Hazar, 1997.

Saunders, G. Recording Britain. London: V\&A, 2011.

Shail, R. British Film Directors: A Critical Guide. Edinburgh: Edinburgh University Press, 2007.

Shapira, M. The War Inside: Psychoanalysis, Total War, and the Making of the Democratic Self in Postwar Britain. Cambridge: Cambridge University Press, 2013.

Silver, A. and J. Ursini. Film Noir ed. Paul Duncan. London: Taschen, 2004. . David Lean and His Films. London: Leslie Frewin Publishers, 1974.

Sissons, M. and P. French, eds. Age of Austerity, 1945-51. London: Hodder \& Stoughton, 1963.

Smith, D. The Spade as Mighty as the Sword: The Story of the Second World War 'Dig for Victory' Campaign. London: Aurum, 2011.

Sparke, P. The Modern Interior. London: Reaktion, 2008.

Spicer, A. Film Noir. Harlow: Pearson Education, 2002.

- Typical Men: The Representation of Masculinity in Popular British Cinema. London: I. B. Tauris, 2001.

Spooner, C. 'Gothic in the Twentieth Century', in C. Spooner and E. McEvoy (eds) The Routledge Companion to Gothic, pp. 38-48. London: Routledge, 2007.

Stead, P. Film and the Working Class: The Feature Film in British and American Society.

London: Routledge, 1989.

Stephens, C. 'Patron and Collector', in C. Stephens and J-P. Stonard (eds) Kenneth Clark: Looking for Civilisation, pp. 79-100. London: Tate Publishing, 2014.

Stevenson, G. The 1930s Home. Princes Risborough: Shire, 2000.

Stewart, J. "I Thought You Would Want to Come and See His Home”: Child Guidance and Pscyhiatric Social Work in Inter-War Britain', in M. Jackson (ed.) Health and the Modern Home, pp. 111-27. London: Routledge, 2007.

Street, S. British Cinema in Documents. London: Routledge, 2000.

—. British National Cinema. London: Routledge, 2007 (first pub. 1997).

_. 'Cinema, Colour and the Festival of Britain, 1951', Visual Culture in Britain 13 (2012), 83-99.

- Colour Films in Britain: The Negotiation of Innovation 1900-55. London: Palgrave Macmillan on behalf of the BFI, 2012.

—_. "Got to Dance My Way to Heaven": Jessie Matthews, Art Deco and the British Musical of the 1930s', Studies in European Cinema 2 (2005), 19-30.

Sugg Ryan, D. Ideal Homes, 1918-1939: Domestic Design and Suburban Modernism. Manchester: Manchester University Press, 2018.

-. 'Spectacle, the Public and the Crowd: Pageants and Exhibitions in 1908', in M. Hatt and M. O'Neill (eds) The Edwardian Sense: Art, Design and Spectacle in Britain, 1901-1910, pp. 43-72. New Haven, CT: Yale University Press, 2010. 
Sweet, M. Shepperton Babylon: The Lost Worlds of British Cinema. London: Faber \& Faber, 2005.

Thompson, L. '1938', in T. Hopkinson (ed.) Picture Post 1938-1950. Harmondsworth: Penguin, 1970.

Thumim, J. 'The Female Audience: Mobile Women and Married Ladies', in C. Gledhill and G. Swanson (eds) Nationalising Femininity: Culture, Sexuality and British Cinema in the Second World War, pp. 238-56. Manchester: Manchester University Press, 1996.

Ward, M. and N. Ward. Home in the Twenties and Thirties. London: Ian Allan, 1978.

Warren, P. Elstree: The British Hollywood. London: Elm Tree, 1983.

Webber, A. The European Avant-Garde 1900-1940. Cambridge: Polity Press, 2004.

Weightman, G. 'Picture Post' Britain. London: Collins \& Brown, 1991.

White, C. L. Women's Magazines 1693-1968. London: Michael Joseph, 1970.

Williams, M. David Lean. Manchester: Manchester University Press, 2014.

Williams, R. The Long Revolution. London: Penguin Books, 1965 (first pub. 1961).

Winship, J. 'Women's Magazines: Times of War and Management of Self in Woman's Own', in C. Gledhill and G. Swanson (eds) Nationalising Femininity: Culture, Sexuality and British Cinema in the Second World War, pp. 127-39. Manchester: Manchester University Press, 1996.

Worsley, J. and K. Giggal. John Worsley's War. Shrewsbury: Airlife Publishing, 1993.

\section{Unpublished material}

Bussing, I. M. 'Haunted House in Mid-to-Late Victorian Gothic Fiction'. PhD thesis. University of Edinburgh, 2010.

Hackney, F. "They Opened up a Whole New World": Feminine Modernity and the Feminine Imagination in Women's Magazines, 1919-1939'. PhD thesis. Goldsmiths, University of London, 2010.

Hockenhull, S. 'Peas, Parsnips and Patriotism: Romantic Images of the Landscape in the Dig For Victory Campaign'. Conference Paper delivered at Screen Studies Conference, Glasgow, 2014.

Mansell, J. 'Sound, Light and the Modern British Home, 1920-1955'. Keynote paper delivered at Domestic Imaginaries: Homes in Film, Literature and Popular Culture Symposium. University of Nottingham, 2014.

Sugg Ryan, D. 'The Empire at Home: The Daily Mail Ideal Home Exhibition and the Imperial Suburb', in Imperial Cities Project, Working Paper No. 6, Department of Geography, Royal Holloway, University of London, 1997.

Warren, G. R. 'The Daily Mail Ideal Home Exhibition 1944-1962: Representations of the "Ideal Home" and Domestic Consumption'. PhD thesis. Middlesex University, 2001. 


\section{Films}

A Man About the House (d. Leslie Arliss, 1947: British Lion Film Corporation)

A Matter of Life and Death (d. Michael Powell and Emeric Pressburger, 1946: Eagle-Lion

Distributors Ltd)

Angels One Five (d. George More O’Ferrall, 1952: Associated British-Pathé)

Black Narcissus (d. Michael Powell and Emeric Pressburger, 1947: General Film

Distributors)

Blithe Spirit (d. David Lean, 1945: General Film Distributors)

Blue Scar (d. Jill Craigie, 1949: British Lion Film Corporation)

Brief Encounter (d. David Lean, 1945: Eagle-Lion Distributors)

Cage of Gold (d. Basil Dearden, 1950: General Film Distributors)

Captain Boycott (d. Frank Launder, 1947: General Film Distributors)

The Captive Heart (d. Basil Dearden, 1946: General Film Distributors)

Come Out of the Pantry (d. Jack Raymond, 1935: United Artists)

The Courtneys of Curzon Street (d. Herbert Wilcox, 1947: British Lion Film Corporation)

The Demi-Paradise (d. Anthony Asquith, 1943: General Film Distributors)

Doss House (d. John Baxter, 1933: Metro-Goldwyn-Mayer)

The Fallen Idol (d. Carol Reed, 1948: British Lion Film Corporation)

The First of the Few (d. Leslie Howard, 1942: General Film Distributors)

The Franchise Affair (d. Lawrence Huntington, 1951: Associated British-Pathé)

Frieda (d. Basil Dearden, 1947: General Film Distributors)

The Glass Mountain (d. Henry Cass, 1949: Renown Pictures Corporation)

Henry V (d. Laurence Olivier, 1944: Eagle-Lion Distributors)

Hue and Cry (d. Charles Crichton, 1947: General Film Distributors)

Ideal Home Exhibition (1947: British Pathé, Unissued/unused material)

I Live in Grosvenor Square (d. Herbert Wilcox, 1945: Pathé Pictures International)

I'll Turn to You (d. Geoffrey Faithfull, 1946: Butcher's Film Service)

In Which We Serve (d. David Lean and Noël Coward, 1942: British Lion Film Corporation)

It Always Rains on Sunday (d. Robert Hamer, 1947: General Film Distributors)

Jassy (d. Bernard Knowles, 1947: General Film Distributors)

Love on the Dole (d. John Baxter, 1941: Anglo-American Film Corporation)

Madonna of the Seven Moons (d. Arthur Crabtree, 1944: Eagle-Lion Distributors)

The Magnet (d. Charles Frend, 1950: General Film Distributors)

Maytime in Mayfair (d. Herbert Wilcox, 1949: British Lion Film Corporation)

Mine Own Executioner (d. Anthony Kimmins, 1947: British Lion Film Corporation)

Mrs Miniver (d. William Wyler, 1942: Metro-Goldwyn-Mayer)

My Brother Jonathan (d. Harold French, 1948: Pathé Pictures Ltd)

The October Man (d. Roy Ward Baker, 1947: General Film Distributors)

Odd Man Out (d. Carol Reed, 1947: General Film Distributors)

The Open Road (d. Claude Friese-Greene, 1925: British Film Institute 2006)

The Passionate Friends (d. David Lean, 1949: General Film Distributors)

Pool of London (d. Basil Dearden, 1951: General Film Distributors) 
The Proud Valley (d. Pen Tennyson, 1940: Associated British Film Distributors)

Quiet Wedding (d. Anthony Asquith, 1941: Paramount British Pictures)

The Red Shoes (d. Michael Powell and Emeric Pressburger, 1948: General Film Distributors)

The Rocking Horse Winner (d. Anthony Pelissier, 1949: General Film Distributors) Say It With Flowers (d. John Baxter, 1934: Radio Pictures)

The Small Back Room (d. Michael Powell and Emeric Pressburger, 1949: British Lion Film Corporation)

Snow White and the Seven Dwarfs (d. David Hand [supervising director], 1937: RKO

Radio Pictures)

Spring in Park Lane (d. Herbert Wilcox, 1948: British Lion Film Corporation)

The Stars Look Down (d. Carol Reed, 1940: Grand National Pictures)

There Was a Young Lady (d. Lawrence Huntington, 1953: Butcher's Film Service)

They Also Serve (d. Ruby Grierson, 1940: Ministry of Information)

They Made Me a Fugitive (d. Alberto Calvacanti, 1947: Warner Bros)

They Were Sisters (d. Arthur Crabtree, 1945: General Film Distributors)

Things to Come (d. William Cameron Menzies, 1936: United Artists Corporation)

This Happy Breed (d. David Lean, 1944: Eagle-Lion Distributors)

The Way to the Stars (d. Anthony Asquith, 1945: United Artists Corporation)

The Years Between (d. Compton Bennet, 1946: General Film Distributors) 